\title{
The Relevance of Theology and Legal policy in South African society in connection with violence against women
}

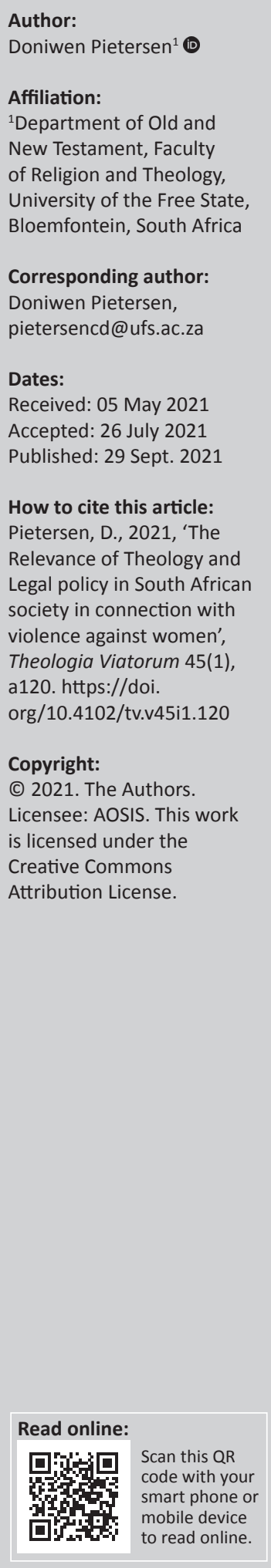

The theological question raised in this article violence against women theologically, drawing and incorporating the South African government's response to it in terms of legislation and policing strategies and the need for greater participation of communities to combat genderrelated crimes. The caretaker approach of the church as the custodian of the Hebrew Bible was also highlighted. Even though a church-based care approach may be limited, it still has the potential to support the efforts of law-enforcement agencies. When women in communities do not feel safe and fear violence at the hands of men, they are forced to resort to the state to provide protection. Crime, including crime against women, draws on insecurities about the level of safety and well-being in communities. It cannot be prevented or eliminated by the police alone but by the concerted collaboration of the private sector, NGOs, faith-based organisations such as churches and the community itself.

Keywords: violence; women; legislation; community; South Africa.

\section{Introduction}

South Africa's female homicide rate in 2020 was five times the global rate. ${ }^{1}$ The numbers are ever increasing and yet violence against women is still regarded as a private affair, with only $3.9 \%$ of women reporting these crimes to the police. ${ }^{2}$ Moreover, some critics claim that the South African Police Service's (SAPS) statistics are inadequate as they do not give an accurate depiction of the full scale of gender-based crimes (Mpani \& Nsibande 2019:8). They claim that the reason the SAPS shies away from supplying more accurate figures regarding genderbased violence is that it would reflect badly on them and would be tantamount to an admission of guilt.

Crime $^{3}$ brings fear, anger and hatred toommunities. Treadwell (2013:07) affirmed that, 'crime is one of the obstacles in improving the quality of life and authorities must take responsibility for community safety'.

It is critical for SAPS and non-governmental organisations, such as Sonke Gender Justice (SDJ), People Opposing Women Abuse (POWA) and Men Engage Alliance to develop strategies to fight crime against women. The decrease of crime in South Africa can bring about positive change, such as job formation and economic development, whereas a high crime rate against women reduces economic expansion and inhibits public safety.

To reduce violence against women, local communities must develop crime prevention programmes in an integrated way. This involves the application of multi-agency programmes that are aimed at reducing the threat posed by violence against women (Pheiffer 2013:14). The National Crime Prevention Strategy (NCPS) ${ }^{4}$ is aimed at improving law enforcement by multidepartmental agencies to attend to the causes of crime against women. To achieve this, South African society must take ownership and acknowledge their responsibility to protect and care for women (Pietersen 2021:199).

1.See the National Police Report of 2020 .

2.These are some of the stark findings of the Gauteng Gender Violence Indicators project study conducted by Gender Links (GL) and the Medical Research Council (MRC). The numbers cover the period from March 2019 to January 2020

3.'Violent crimes against women impacts on communities' (Treadwell 2013:07). Crime perpetrated against women is defined by Taye (2011:09) as emotional and physical abuse, which makes women feel insecure about their safety. Davies, Croall and Tyrer (2009:40), on the other hand, define violence against women as any act or omission that is prescribed by criminal law and is punishable by the authorities through the criminal justice process.

4.National Crime Prevention Strategy. 


\section{The background to violence against women thriving in South Africa}

Violence against women is evidenced in regional data as well. For example, over half the women in Gauteng (51.3\%) have experienced some form of violence (emotional, economic, physical or sexual) from men in their lifetime and $75.5 \%$ of men in the province admit to perpetrating some form of violence against women. Emotional violence - a form of violence not well defined in domestic violence legislation and thus not well reflected in police data - is the most commonly reported form of violence, with $43.7 \%$ of women saying they experience it and $65.2 \%$ of men admitting to its perpetration. One in four women in Gauteng has experienced sexual violence in their lifetime. An even greater proportion of men (37.4\%) disclosed perpetrating sexual violence (Krug, Sethi \& Holder 2002:10). Where violent behaviour against women occurs that is in breach of legislation or decisions made by courts of law, punishment must be swift and criminal proceedings should be expedited.

Crime in general is caused by three factors, namely the offender, the potential victim and the environment (Smit, Minnaar \& Schneitler 2004:74). However, this should be elaborated on more specifically in policy documents for uniformity in applying punishment for crimes perpetrated against women. In the Western Cape, for instance, research by Gender Links revealed that perpetrators themselves are not aware of what constitutes violent crime against women. To address this issue, education about these crimes must precede the work of law enforcement agencies, whilst applying proper punishment (Pietersen 2021:202).

\section{Reducing violence in South African society - police prevention}

Referring to Pheiffer (2013:15), 'policing is an approach to community safety where there is a networking of service providers that interact to ensure the safety and security of communities'. This is needed in a crime-riddled country such as South Africa for the abuse of women to become a high priority for the police:

The SAPS must take into consideration the community's harsh attitude towards women in executing their daily duties. Policing can be effective if it is done through an integrated approach where crime-prevention responsibilities are shared with the community. (Pheiffer 2013:16)

This integrated approach could signal a downward trend in the violence seen recently against women, including highprofile cases such as Uyinene Mrwetyana and others like her (Landman \& Liebermann 2005:25).

\section{Cooperation and collaboration to fight violence against women}

Violence against women is a crime, but it is also 'a social matter which involves entire communities' (Smit et al. 2004:80-81). For crime deterrence projects to succeed in curbing violence against women, there must be partnerships between the police and other role players. The South African Police Service Act (on CPFs of 1995) ${ }^{5}$ 'makes provision for the development of a policing policy and to build partnerships with communities and civil society' (Smit et al. 2004:80), as far as violence against women is concerned. Crime prevention around the abuse of women is therefore a joint responsibility shared by 'government departments, NGOs, communitybased organisations and individuals' (Smit et al. 2004:81).

Communities themselves also need to take responsibility for the safety of women. The benefits of police collaboration with communities and private and non-governmental organisations are as follows (Pietersen 2021):

- Increased awareness through campaigns.

- Greater levels of trust.

- Greater police visibility.

- Better care of the vulnerable, including women. (p. 203)

However, according to Smith et al. (2004:82), there seems to be a lack of partnership between the police and communities because partnerships are either broken or non-existent. This is an area that needs to be improved:

At the crux of partnerships involving law enforcement agencies is the belief that reducing crime and disorder requires the coordinated, concentrated effort of individuals and organisations affected by and concerned with the problem of violence against women. (Skogan 2004:06)

If this kind of coordinated strategy is thoroughly active between collaborative policing organs then lasting change for women to feel protected and valued in society maybe immanent (Pheiffer 2013:17).

The SAPS and resident communities must build an atmosphere of trust to take responsibility for the safety of women. Where the skills and resources of the community are not properly harnessed by law-enforcement agencies, violence against women stubbornly persists and the cycle of aggression continues.

\section{Consequences of communities fighting violence against women}

Community crime prevention aimed at reducing violence against women ought to be a 'collaboration between the police and communities as a means to bring offenders to book' (Mudau 2008:27). Community crime prevention often takes the form of neighbourhood watches, which started as vigilantism during apartheid, based on the need for selfprotection. Its main emphasis is on community awareness and taking proactive measures against any signs of abuse

5. The SAPS ACt provides for specific roles of the police in relation to community safety. These include establishing and maintaining partnerships with the community, promoting communication with the community, enhancing cooperation on policing with the community improving transpar with the community, improving transparency and accountability to the community, improved partnership with the community, improved service delivery at all levels and joint problem identification the development of acontironment and hav access to high-quality services in their communities, through integrated and coordinated multi-agency collaboration amongst organs of state and various communities. 
towards women. This strategy to reduce public fear of crime could be an effective means of developing local partnerships. However, according to Skogan (2004:06), violence against women can only be reduced if communities collaborate with the police and non-governmental organisations. Police agencies cannot deal with the issue of crime against women without the assistance of the community. When violent crime against women escalates, it is a sign that the community is fragmented and disorganised. The only way community crime prevention can work is through residents forming patrols and neighbourhood watch groups.

'Community policing is rooted in the law enforcement's dependence on the public's eyes, ears, information and influence to exert social control' (Miller, Hess \& Orthmann 2014:79). According to Krug et al. (2019:11), the Gauteng Department of Community Safety has occupied the chief role in public crime deterrence by launching a communal patrol programme with the aim of tackling the spike in violence against women and children.

\section{Legislation to protect women against gender- based violence}

According to the SAPS Act, the provincial commissioner may delegate the function of crime against women to station commanders. It is then the concern of station commanders to establish community police forums. The act stipulates that the SAPS must therefore, 'establish and maintain partnerships within communities with the purpose of promoting joint problem identification and problem solving' (Roelofse 2007:79). This collaboration has the potential to result in a rapid decrease in female abuse in vulnerable communities.

Pheiffer (2013:60) interpreted the objectives of police collaboration as mobilising and empowering communities. If the relationship between the police and the community is not well managed, it may result in cases being poorly handled and ultimately remaining unresolved. This can occur where, 'there is a lack of awareness and therefore no joint identification of crime hotspots by both the SAPS and local communities' (Pheiffer 2013:61). Scarce resources remain a real challenge in creating lasting partnerships in crime prevention that will be able to tackle the increase in gender violence. From a historical perspective, it should be observed that many communities today still struggle to trust the police because during apartheid, the police was viewed as the arm of state-sponsored violence against the oppressed.

\section{Constitution of the Republic of South Africa (Act 108 of 1996)}

The representation of the new constitution provided a context for the formation of community structure through the Community Police Forum (CPFs), 'police accountability and civilian oversight of the SAPS. In terms of Section 205 of the Constitution of the Republic of South Africa, 1996' (Smit et al. 2004:13), the aims of the SAPS are well-known as follows, according to the National Gender-Based Violence and Femicide Strategic Plan, 2019:

To prevent, combat and to investigate crime for the benefit of all South Africans. Protect and secure the inhabitants of the Republic of South Africa and their properties. SAPS must protect all people, but especially vulnerable people, such as women, children and those with disabilities against abuse, violence and criminality. This includes upholding and enforcing the law. They must also execute the law to the satisfaction of all communities. However, without the involvement of communities as the active partner in preventing crime, the abuse of women, children and people with disabilities will not be sufficiently reduced. (NGB Violence \& Femicide Strategic Plan 2019)

Although the constitution makes specific provisions for the protection of women, if the SAPS and other crimeprevention organisations do not enforce them, violence against women may continue to increase. According Krug et al. (2019:13), violence against women is still regarded as a private affair, with only $3.9 \%$ of women reporting this crime to the police because of the stigma of singling out men whom they know personally, usually their boyfriends or husbands. For many women, there is often a sense of despondency or that the system is weighted against them and that the police will do little to help them even if they do report the abuse (Pietersen 2021:210).

\section{South African Police Service Act (Act 68 of 1995)}

This law concentrates on the formation and conservation of partnerships 'between the SAPS and the community', cultivating transparency and service delivery within 'the SAPS and promoting communication' and cooperation between the police and local communities. In other words, Section 19 of SAPS was established to allow communities to have direct involvement in crime prevention (Smit et al. 2004:13-14).

The SAPS Act 68 of 1995 is the state's response to the cry of civil society for a safe country where women, children and gender non-conforming individuals are notorious and esteemed, 'and in which gender-based violence and femicide will not be tolerated' (Smit et al. 2004:15).

\section{National Development Plan (2030)}

The visionary 'National Development Plan (2030) was formulated to ensure a decent life for all South Africans by eliminating poverty and reducing inequality' (Minnaar 2009:20), including racial, income and gender inequality. The fundamentals of this plan to improve the normal life are as follows:

- To ensure that all South Africans have access to decent housing, water, electricity and sanitation and as a consequence reduce crime and other and social problems such as the abuse of women and children. 
- To provide better safety and security. However, it is not clear whether the National Development Plan (NDP) will play a role in curbing gender-based violence.

- To equip all South Africans with quality education and skills development. By providing better education and developing the skills of women, crimes against them are expected to automatically be reduced.

- To provide safer and more reliable public transport, which the NDP anticipates will reduce the incidence of robbery and rape, as women will not have to wait unattended for long periods at taxi ranks and bus stations.

In order for abuse against women to end, the destructive culture of violence against women as a means of solving conflicts domestically and socially must be exposed and condemned (Minnaar 2009:20-25).

\section{Theological approaches that empowers women}

The investigation surrounding the disempowerment of and violence against women attempts to investigate how both culture and the Old Testament and law enforcement bodies deal with the ability to care for victims and to help change the attitudes and actions of perpetrators of these crimes. It has been observed that the state's response to violence against women is limited to enforcing laws, especially when the necessary collaborative efforts from communities do not exist. However, if these two elements do not intersect, violence against women will only be sustained and legitimised. As an alternative, a biblical church method will be examined and presented as the chosen source from which commendations will be attained. This will then not only serve as a framework from which an alternative approach to curbing violence against women may be drawn but will also become part of an integrated platform from which law enforcement bodies can undergird their attempts to prevent these crimes (Pietersen 2021:215).

'Scripture and the biblical interpretation with regard to women in the Old Testament', yield insights into how women were disempowered (Pierce \& Groothuis 2004:17). For example, in case law:

If a man has two wives, the one loved and the other unloved, and both the loved and the unloved have born him sons, if the firstborn son belongs to the unloved, then it shall be in the day he wills what he has to his sons, he cannot make the son of the loved the firstborn before the son of the unloved, who is the firstborn. But he shall acknowledge the firstborn, the son of the unloved, by giving him a double portion of all that he has, for he is the beginning of his strength; to him belongs the right of the firstborn. (Dt 21:15-17)

In acknowledging this legacy and in seeking to change the prevailing attitude towards women in South Africa, a theological perspective should be welcomed. McClure (2012:269) posited, 'a form of religious engagement aimed at integrating theory, theology and practice within the context of a faith community' is necessary in order to bring healing to women who have fallen victim to abuse. In addition, healing this approach includes guiding people on issues related to sin, suffering, healthy Christian doctrine, understanding 'that men and women are created in God's image' (Van Arkel 2000:148), nurturing a balanced view of Scripture and formulating liberating gender-inclusive language. Approaches of this kind all underwrite to enable a healthy, empowering attitude towards women to prevail to curb violence against them.

\section{A Hermeneutic of caring for vulnerable and abused women}

Van Arkel (2000:146) declared that the attentiveness of feminists and womanists to the dynamic of suffering caused by the hierarchical ordering of relationships has made an enormous impact on theology'. The theology of suffering is an integral part of the Hebrew Bible. The idea of suffering is also a central theme to the experience of women facing violence in South African society. Women who are subjected to violence in marriage are often encouraged by faith-based organisations to stay in these abusive relationships and to 'endure suffering as a sign of obedience to God' (Jones 2000:10). This is often met with 'feelings of helplessness' and indignation. As a result, this approach often 'causes victims to remain silent about their abuse' (Cornelius 2013:187).

Attitudes in the church need to be interrogated and dispelled by the care approach. Furthermore, faith-based organisations should critically engage with the theology of suffering, as well as its insistence on the preference of the permanency and preservation of marriage. In order to help women who are disempowered and abused, faith-based organisations should promulgate in society 'a suffering theology that affects lives' (Ford 2007:2).

Du Plessis (2015:5) asserted that the theology of suffering must inculcate a sense of care to vulnerable and abused women. This may include a deliberate and clear reframing of the permanency of marriage where one partner is physically, emotionally or verbally abusing the other.

\section{The virtue of empowering women}

Doctrine with regard to the Hebrew Bible and violence against women can be linked. Watson (2002:34) pointed out that the concept of maleness is prominent in traditional Judaism. This is manifested in the maleness of God. God's characteristics are often viewed as essentially male and nothing else. His more feminine characteristics, such as his love and care for his creation, are not emphasised. As a result, men in society often exert a 'God complex' in relation to women. This then creates a platform for men to disparage women and for women in turn to feel disempowered.

In response to this, Watson (2002:35) recommended that faith-based organisations promote 'a theology of healthy liberation'. This should allow women to connect with Yahweh's other characteristics that are not exclusively male. Bennet Moore (2002:84) stated that Christ 'proclaimed the 
love of God for the least and renounced systems of domination', together with women, as 'they are amongst the least in this world'. I would argue that all doctrine teachings about God ought to be liberating to women and should be unstated as a 'theological discourse that challenges structural changes in church and society'. This would enable women to experience the compassion and love of God and for them to feel appreciated and celebrated in church and in society.

Yahweh in the Hebrew Bible ought to be a 'revolutionary of equality' (Furlan 2009:242). As faith-based communities, our interactions with the Hebrew Bible must encourage us to uphold women's dignity and revive respect for them in the minds of men.

Communities ought to live by the true insolence of God to women, captivating precise cognisance of his communion with them and his efforts to create 'the dignity and equality of women' (Furlan 2009:243). This hermeneutical assignation with the biblical text will reveal the 'original Christian doctrine' founded on the boldness of Jesus, who 'not only preaches and protects and nurtures gender equality or life in equal respect and solidarity, but sets it as an imperative and the core of all interpersonal relationships' (Furlan 2009:245). This would enable women to feel included in the formation of church doctrine.

In order to assert the principle of care for women and to curb the disempowerment of and violence against women, the church needs to embrace a feminist hermeneutic. By doing so, it will ultimately help to liberate women from destructive power structures in society and address the issue of violence against them. It will also enable women to resist the oppression they may be suffering in abusive relationships and to feel empowered to make a difference in their lives.

\section{Created equal- image of God}

To empower women is to engage with the image of God because of the theological understanding that humanity is made in the image of God. This is a golden thread in the Hebrew Bible. The image of God that is held by individuals will determine the image they have of themselves and of others. Society as it is today has gone the other way. The overemphasis of masculinity to the detriment of femininity in relation to God's nature has only served to men's advantage.

Society derives its dynamics of power, domination and control from an understanding of the masculine construct. 'This power is mostly exercised over women, given the gender hierarchy of the superiority of men over women' (Klopper 2002:245). When the supremacy of men is defied within society, either by external threats such as unemployment or by the dehumanising influence of racism, it often results in violence against women as an attempt to reassert male dominance and power:
Masculinity comes in the form of images of God as king, judge, ruler and warrior, which all portray the concept of male superiority, power, domination and control in the Hebrew Bible. The almost exclusively male images ascribed to God imply that men are more like God or closer to God's image. (Klopper 2002:426)

In the patriarchal images ascribed to God from the Ancient Near East (ANE) context of the Bible, God is portrayed as allpowerful, authoritarian, dominant and in control. It is these perceived characteristics that men ascribe to in their quest for masculinity, to be like God and to maintain their superiority. Vulnerability is seen as a weakness, falling into the realm of what it means to be a woman (Rakoczy 2000:15). What is most important and expected from society is to give the impression of strength (Anderson 2016:40).

To counter these ideas in the church and ultimately in society, the notion of helplessness relative to God should be considered. Anderson (2016:41) affirmed this by stating that, 'the belief is often insisted upon that God is exclusively powerful'. The notion of God as being helpless and 'susceptible to being wounded' is labelled by Anderson as 'too much divine weakness for some believers'. This concept of an all-powerful God 'allows men to preserve their presumption of power and privilege and circumvent the world's suffering or their personal vulnerability', especially towards women (Claassens 2014:50).

Faith-based organisations should 'engage with the paradoxical notion of the power and vulnerability of God' (Topalli, Brezina \& Bernhardt 2013:60). A reconstructed image of God that displays both his male and female characteristics would enable men and women to rediscover their humanity in a different light. Rather than projecting a traditional patriarchal image of God in society, the church should emphasise that both men and women are vulnerable beings. The beauty of this may result in responsible care for 'others in the form of healing, liberating, guiding and transforming not only victims but also culprits of abuse' (Claassens 2014:70).

\section{Using a feminist reading of the Old Testament to contextualize the empowering of women in a modern society (South Africa)}

The majority of contemporary South African society does not view the Old Testament in the Hebrew Bible favourably. This is because of unhelpful gender-biased interpretations of biblical texts, especially those related to women. This attitude sets a patriarchal tone as to how women are treated by society (Furlan 2009:238).

Watson (2002:10) may offer a solution by stating that the 'constant and dynamic engagement with all its [Old Testament] aspects' will allow faith-based organisations to engage:

$[I] n$ a feminist hermeneutical process of a critical and constructive reading of Scripture. This process involves reading the text with an awareness of its context and interpreting it in the light of women's experiences. (Watson 2002:10, 5) 
Disempowerment of women, and the language surrounding it, ought not to limit a womanist approach to hermeneutics. To elaborate this point further, it is said that womanist approaches:

... [S]peaks specifically about the use of language in biblical translations. It is her understanding that what can be done to change the linguistic sexism in biblical translations is limited. The use of gender-inclusive language in biblical translations is an extremely necessary action to help society place a higher value on women. (Bennet Moore 2002:65)

This will enable the 'humanity of women as full members of the Christian church' and of society to stand out (Watson 2002:5). According to Cornelius (2013):

A necessary challenge faced by the church is to engage with, deconstruct and re-interpret Scriptures that may serve to perpetuate and justify the oppression of women through violent abuse. (p. 189)

To do this, I would suggest that churches focus on reinterpreting Scriptures that bear the hallmarks of the patriarchal nature of ANE culture in which they are steeped. These problematic texts should be challenged, particularly in the South African context where the disempowerment of and violence against women are almost condoned and the abuse experienced by women is normative (Petersen 2009:451).

\section{Using gender liberation to move towards women empowerment}

Language can be a defining feature for society and how women in general are treated (Neuger 1996:94). Language constitutes people and social discourses. As human beings, we are all to some extent controlled by ways of thinking and doing based on social discourses. This includes the worship that exists in faith-based communities, but if society is able to recognise that, 'sexist language constructs women ... [as] powerless in the face of social injustices such as domestic violence' (Landman 2006:278), it might go some way to improving the agency of women.

Rakoczy (2003:43) reiterated this by recommending 'the use of inclusive language as a practical suggestion to prevent violence against women'. As a society steeped in violence and abuse against women, it would be responsible to illustrate care towards victims of violence. In order to do this, the reconstruction of language is critical in faith-based communities to become more gender inclusive (Pietersen 2021:223-224).

\section{Conclusion}

This article has shown that violence and disempowerment of women is a phenomenon that has persisted over the ages and finds manifold expression. In South Africa, where women are negatively impacted by gender-based violence and discrimination, a lack of clear policy directive means that any inhumane treatment of women does not always result in severe punishment. Notwithstanding the fact that women are equal to men and made in the image of Yahweh, South African women are often neglected, abandoned and lack sufficient legal status, as a result of which society loses out on the immense value that they could potentially bring.

\section{Acknowledgements Competing interests}

The author declares that he has no financial or personal relationships that may have inappropriately influenced him in writing this article.

\section{Author's contributions}

D.P. is the sole author of this research article.

\section{Ethical considerations}

This article followed all ethical standards for research without direct contact with human or animal subjects.

\section{Funding information}

This research received no specific grant from any funding agency in the public, commercial or not-for-profit sectors.

\section{Data availability}

Data sharing is not applicable to this article as no new data were created or analysed in this study.

\section{Disclaimer}

The views and opinions expressed in this article are those of the author and do not necessarily reflect the official policy or position of any affiliated agency of the author.

\section{References}

Anderson, H., 2016, 'Leaving the door to the soul ajar: Rethinking masculinity', Word \& World 36(1), 36-44.

Bennet Moore, Z., 2002, Introducing feminist perspectives on pastoral theology, Sheffield Academic Press, London.

Claassens, L.J., 2014, 'The Rhetorical Function the woman in Labor Metaphor in Jeremiah 30-31: Trauma, gender and postcolonial perspectives', Journal of Theology for Southern Africa 150(1), 67-84.

Cornelius, E., 2013, 'Only real men respect women: The use of scripture in the violence against women pandemic', Ekklesiastikos Pharos 95(1), 173-190.

Davies, M., Croall, H. \& Tyrer, J., 2009, Criminal justice, Pearson Education, Bloemfontein.

Du Plessis, A.L., 2015, 'Principles for the pastoral guidance process to women on matters related to human vulnerability and personal integrity', HTS Theological studies 71(2), 1-6. https://doi.org/10.4102/hts.v71i2.2068

Ford, G.W., 2007, 'Tolerating and staying: How a theology of female submission contributed to the prevalence of women tolerating and staying in violent situations', E-Quality 6(3), 1-5.

Furlan, N., 2009, 'Institutionalised Christianity and the question of gender hierarchy', Drustvena Istrazivanja 30(1), 233-248. https://doi.org/10.5559/di.20.1.12

Jones, S., 2000, Feminist theories and Christian theology: Cartographies of grace, Fortress Press, Minneapolis, MN.

Klopper, F., 2002, 'Women, monotheism and the gender of God', In die Skriflig 36(3), 421-437. https://doi.org/10.4102/ids.v36i3.516

Krug, E; Sethi, D \& Holder, Y., 2019, Violence: a public health priority, Switzerland, WHO Publishers.

Landman, C., 2006, 'Can justice be embodied in sexist language? A challenge to the Confession of Belhar', Dutch Reformed Theological Journal 47(2), 283-290. 
Landman, K. \& Liebermann, S., 2005, 'Planning against crime. Preventing crime with people not barriers', SA Crime Quarterly 11(3), 21-26.

McClure, B., 2012, 'Pastoral care', in B.J. Miller-McLemore (ed.), The Wiley-Blackwell companion to practical theology, Blackwell Publishing Limited, West Sussex.

Miller, L.S., Hess, K.M \& Orthmann, C.M.H., 2014, Community policing: Partnerships for problem solving, Delmar, New York, NY.

Minnaar, A., 2009, 'Community policing in a high crime transitional state: The case of South Africa since democratisation', in D. Wisler \& I.D. Onwudiwe, Community policing international patterns and comparative perspectives, $\mathrm{pp}$. 35-72, Routledge, CRC, Boca Raton, FL.

Mpani, P. \& Nsibande, N., 2019, Understanding gender policy and gender-based violence in South Africa, Soul City, Institute for Health and Development Communication, Johannesburg.

Mudau, M.E., 2008, The implementation of sector policing in the Limpopo Province, Unisa Press, Pretoria.

Neuger, C.C., 1996, Counselling women: Narrative pastoral approach, Fortress Press, New York, NY.

Petersen, E., 2009, 'Addressing domestic violence: Challenges experienced by Anglican Clergy in the Diocese of Cape Town, South Africa', Social Work \& Christianity 26(4), 449-469.

Pheiffer, D.C., 2013, Analysis of the role of South African Police Service and Local Government in Crime Prevention, Unisa Press, Pretoria.

Pierce, R. \& Groothuis, R., 2004, Discovering biblical equality: Complementary without hierarchy, InterVarsity Press, Downers Grove, Illinois, IL.

Pietersen, C.D., 2021, 'Disempowerment of and violence against women: Old Testament perspectives', Unpublished Thesis, University of Pretoria, Pretoria.
Rakoczy, S., 2000, Silent no longer: The Church responds to sexual violence, Lumko Institute, Pietermaritzburg Agency for Christian Social Awareness: National Justice and Peace Commission, SACBC: Theological Advisory Commission, SACBC, Johannesburg.

Rakoczy, S., 2003, In Her Name: Women Doing Theology, Pietermaritzburg, Cluster Publications.

Roelofse, C.J.N., 2007, The challenges of community of policing: A management, LexisNexis, Durban.

Skogan, W.G., 2004, Fairness and effectiveness in policing: The evidence, The National Academic Press, Washington, DC.

Smit, J., Minnaar, A \& Schnetler, J., 2004, Smart policing for law-enforcement officials, Van Schaik, Pretoria.

South African Government, 2019, National Gender-Based Violence and Femicide Strategic Plan, viewed on November 2020, from https://www.gov.za/documents/nationalgender-based-violence-and-femicide-strategic-plan-draft-12-aug-2019-0000.

Taye, K.A., 2011, Assessing factors that affect the implementation of community policing in Awassa, University of South Africa, Pretoria.

Topalli, V., Brezina, T. \& Bernhardt, M., 2013, 'With God on my side: The paradoxical relationship between religious belief and criminality among hardcore street offenders', Theoretical Criminology 17(1), 49-69. https://doi.org/10.1177/1362480612463114

Treadwell, H.M., 2013, Beyond stereotypes in Black and White: How everyday leaders can build healthier opportunities for African American boys and men, ABC-CLIO, California, US

Van Arkel, J., 2000, 'Recent movements in Pastoral theology', Religion and Theology 7(2), 142-168. https://doi.org/10.1163/157430100X00027

Watson, N.K., 2002, Feminist theology, William B Eerdmans Publishing Company, Grand Rapids, MI. 